\title{
47. EVOLUTION OF THE CENTRAL EXMOUTH PLATEAU: A POST-DRILLING PERSPECTIVE1
}

\author{
Bilal U. Haq, ${ }^{2}$ Ronald L. Boyd,${ }^{3}$ Neville F. Exon, ${ }^{4}$ and Ulrich von $\operatorname{Rad}^{5}$
}

\begin{abstract}
During Leg 122 the JOIDES Resolution occupied two sites (762 and 763) on the central Exmouth Plateau. The drilling target in the older part of the cored section was a Neocomian wedge of clastic sediments, sourced from the south so that Site 763 was located proximally and Site 762 distally to sediment source. Multiple objectives of the leg included: (1) dating of final breakup of the southern Exmouth Plateau and its evolution from a juvenile to mature oceanic margin; (2) delineation of depositional sequences associated with progradation of the Neocomian clastic wedge; (3) refinement of Mesozoic and Cenozoic magnetobiostratigraphies; and (4) recovery of a complete Cretaceous/Tertiary boundary section.

Well-constrained dating of the unconformities associated with tectonic events has narrowed considerably the age of the final fragmentation of the plateau to late Valanginian when Greater India broke away from the southwestern margin, initiating the formation of the Gascoyne and Cuvier abyssal plains to the west and southwest of the plateau.

Sequence-stratigraphic concepts applied to the Berriasian Barrow Group sediments have revealed the presence of several depositional sequences (at least four in the cored part of Site 763) and provide a valuable case study of an ancient lowstand prograding complex with high clastic influx.

Refined multifossil biostratigraphy for much of the recovered Cretaceous and Cenozoic section was possible. Attempts at paleomagnetic analyses produced an incomplete but partially useful magnetostratigraphic record of the Late Cretaceous and Cenozoic. An essentially complete Paleogene and nearly complete Neogene record is present at Site 762 which lent itself to detailed biostratigraphic zonation.

Given the good palynological (microplankton) biostratigraphic resolution available for the Neocomian part of the section, but less than definite correlation to global biostratigraphic schemes, the timing of sea-level events on the central Exmouth Plateau appear to agree well with the eustatic cycle chart, suggesting a global influence superimposed on the local and regional tectonics.
\end{abstract}

\section{INTRODUCTION}

Ocean Drilling Program (ODP) Leg 122 on the Exmouth Plateau was one of the rare occasions when scientific drilling sampled an old passive continental margin. Drilling on a margin with known hydrocarbon occurrence, without the benefit of a protective bottom-hole assembly and riser system, elicited obvious safety concerns. But the scientific objectives were compelling enough that a drilling strategy was designed to core near previously drilled, but relatively poorly sampled, exploratory industry holes that did not have significant hydrocarbon shows. This unprecedented experiment yielded an important record of the late-rift and postbreakup sedimentary history and paleoenvironmental evolution of this margin. Site 762 was drilled approximately $2 \mathrm{~km}$ northwest of the industry well Eendracht-I to a depth of 940 meters below seafloor (mbsf), and Site 763 was drilled near well Vinck-I to a depth of $1036.6 \mathrm{mbsf}$, about $2 \mathrm{~km}$ southeast of the well site (Fig. 1).

The availability of well-log data from these and other commercial wells and an extensive network of high-quality seismic data on the Exmouth Plateau were important factors in choosing this area as a case study of the development of sediment-starved passive margins, where various models of

\footnotetext{
${ }^{1}$ von Rad, U., Haq, B. U., et al., 1992. Proc. ODP, Sci. Results, 122: College Station, TX (Ocean Drilling Program).

2 Division of Ocean Sciences, National Science Foundation, Washington, DC 20550, U.S.A.

${ }^{3}$ Department of Geology, Dalhousie University, Halifax, Nova Scotia B3H 3J5, Canada.

4 Bureau of Mineral Resources, Canberra ACT 2601, Australia.

${ }^{5}$ Bundesanstalt für Geowissenschaften und Rohstoffe, D-3000 Hannover, Federal Republic of Germany.
}

margin evolution could be tested. Several such models have been proposed (e.g., Falvey, 1974; Mauffret and Montadert, 1987; Lemoine and Trümpy, 1987) that envision the mechanism of margin development in terms of uplift and subsidence cycles, or varying thermal response of oceanic and continental lithosphere. For example, recent seismic data from Exmouth Plateau show large rotated fault blocks and two prominent landward-dipping, subhorizontal, mid-crustal detachment faults under the central plateau (Williamson et al., 1990). Mutter et al. (1989) suggest that the outer part of Exmouth Plateau (near Site 762) was produced by lithospheric thinning and pure shear (high-angle normal faults and McKenzie-type stretching), and postdates the thin-skinned deformation with simple-shear detachment systems (Wernicke-type deformation) under the central part of the plateau (near Site 763).

\section{GEOLOGICAL BACKGROUND}

Exmouth Plateau is a part of the northern Carnarvon Basin, which is structurally subdivided into Dampier, Barrow, and Exmouth sub-basins, and whose stratigraphy is detailed by Hocking et al. (1987). The basin is itself a part of the Westralian Superbasin, which received up to $10 \mathrm{~km}$ of sediments from the Permian through the Mesozoic. The Westralian Superbasin formed a part of the northern margin of Gondwana bordering the Neo-Tethys Ocean (Bradshaw et al., 1988), characterized largely by Triassic clastic sedimentation. Segmentation of the superbasin into platforms and troughs occurred in the Jurassic. Thick marine sequences filled the troughs, while high areas such as the central and western Exmouth Plateau received little or no sediments (Barber, 1982, 1988; Exon and Willcox, 1978; Boyd et al., this volume; and Exon et al., this volume, chapter 12).

Structurally the Exmouth Plateau is dominated by highangle faults, trending northeast-southwest or north-south, that 


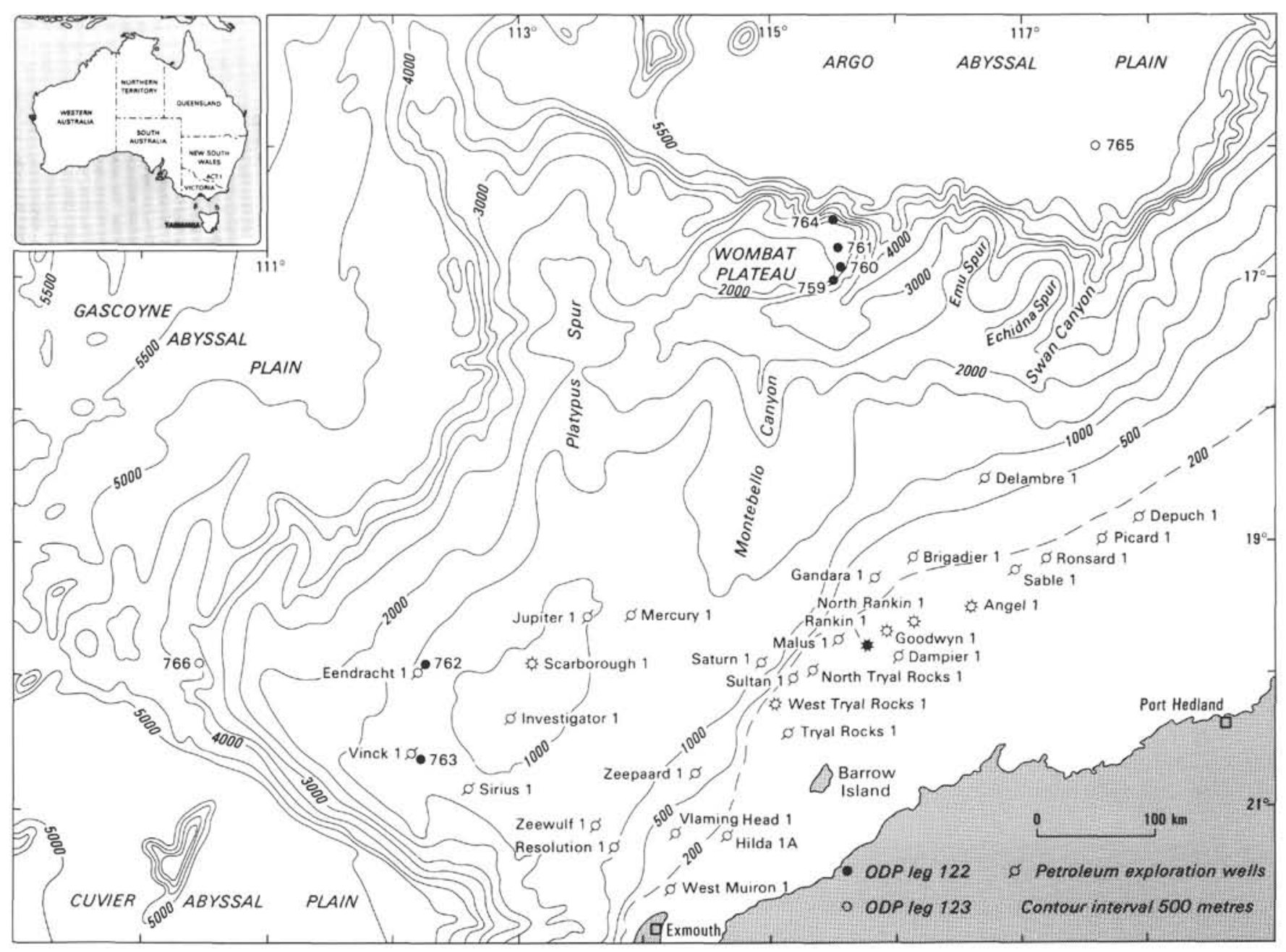

Figure 1. Map of the Exmouth Plateau showing bathymetry in meters, ODP drill sites, and exploration well sites (standard industry symbols).

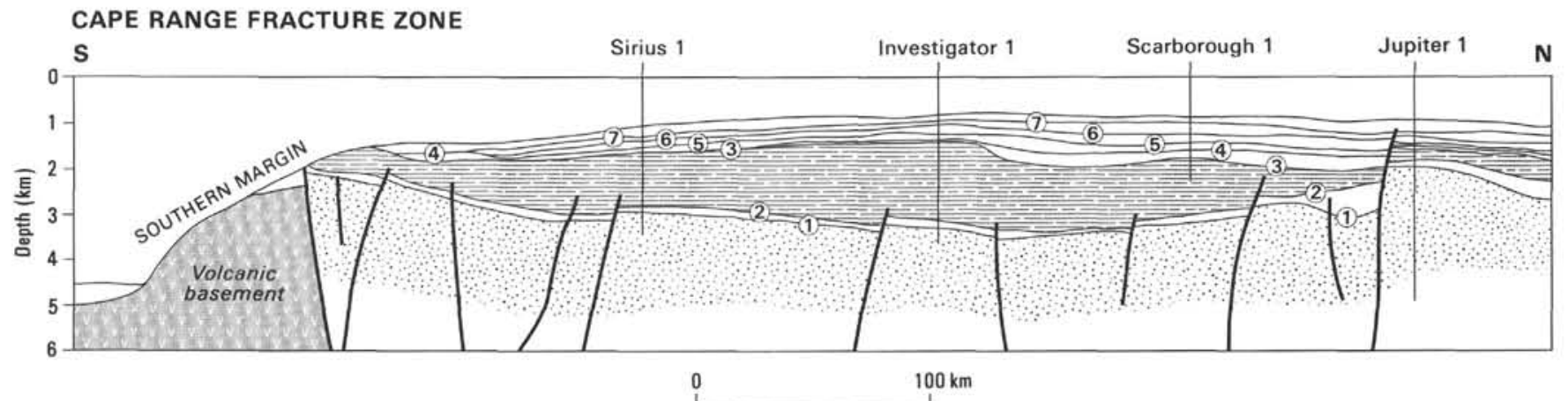

Figure 2. A north-south synthesis cross-section over the Exmouth Plateau and Kangaroo Syncline showing eight seismic packages (the lowermost below reflector 1 and the uppermost between reflector 7 and the seafloor) identified by Boyd et al. (this volume). The Neocomian seismic package 3 (between reflector 2 and 3) can be seen to prograde away from the southern transform margin. (For a discussion of sequence-stratigraphic interpretation of package 3, see text and Fig. 5, back pocket).

cut through the rift-onset unconformity (Fig. 2); they appear to have both normal and strike-slip origins. The faults parallel the Precambrian structural trend of the West Australian cratonic blocks (Barber, 1988; Boyd et al., this volume). Near the southern margin of the plateau the structural trend changes to northwest-southeast. The high-angle faults form a series of horsts, grabens, and half-grabens, with minor throws and clockwise rotation along the fault blocks on the south central plateau, but greater throws and rotation near the margins toward the Kangaroo Trough. Mutter et al. (1989) documented two deep reflectors not cut by high-angle faults, which they interpreted as surfaces of decollement, represent- 


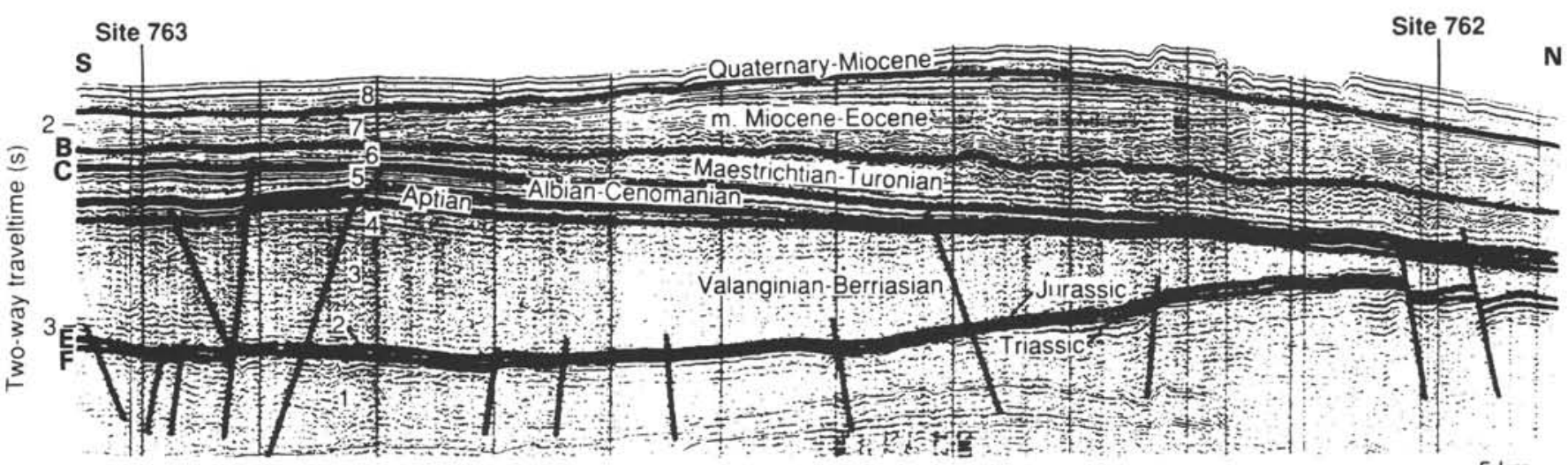

Figure 3. ODP seismic line between Sites 763 and 762 showing the northward thinning of the Berriasian-Valanginian clastic sediment wedge and the northward thickening of latest Cretaceous-Tertiary deep-water carbonate sediments (after Haq, von Rad, O'Connell et al., 1990).

ing detachment that may have occurred during the Jurassic rifting episode of the plateau.

The present Exmouth Plateau is bordered on the northeast, west, and southwest by the Argo, Gascoyne, and Cuvier abyssal plains, respectively (Fig. 1). The latter two formed after Neocomian rifting and seafloor spreading (Exon et al., 1982). Accelerated late-rift subsidence of the basin and uplift of the southern hinterland, followed by rapid erosion, caused the blanketing of the southern plateau in the Berriasian and early Valanginian with deltaic sediments up to $2 \mathrm{~km}$ thick. These are overlain by hemipelagic late Neocomian sediments and by marine carbonates of Late Cretaceous and Tertiary age.

Figure 3 shows ODP seismic profile 122-6 collected during Leg 122 between Sites 762 and 763 (Haq, von Rad, O'Connell, et al., 1990). The most prominent feature is the northward thinning of deltaic Berriasian to early Valanginian sediments equivalent to the Barrow Group, sourced from the south. The sudden influx of deltaic sediments in the Berriasian was terminated on the western Exmouth Plateau at the end of the early Valanginian. There is evidence that a major ridge up to $2000 \mathrm{~m}$ high formed above the future Cape Range Fracture Zone (the southwest breakup boundary of the Exmouth Plateau) because of to thermal doming. Erosion of the ridge provided sediments for the thick outbuilding of the Barrow Group (Veevers and Powell, 1979; Exon and Buffler, this volume). When the ridge collapsed after breakup, the sediment supply was suddenly cut off at the end of the early Valanginian. In the Barrow Sub-basin and on Exmouth Plateau a south-eastern source of sediments also may have been operative in the earliest Cretaceous (Boote and Kirk, 1989). Boyd et al. (this volume) indicate that this was in part an area of uplift along the rift which was to form the eastern margin of the Cuvier Abyssal Plain, and was also cut off from the source of sediment supply in the late Valanginian. (The stratigraphic record of the Exmouth Plateau sites is summarized in Fig. 4. For a more detailed discussion of the origin and distribution of the recovered sediments see Exon et al., this volume, chapter 12).

The Barrow Group-equivalent sediments (Fig. 4) were laid down by deltaic progradation in a northward direction in the Barrow Sub-basin and on the southern Exmouth Plateau. In the former sub-basin the Barrow Group is well developed, commonly 500-1000 m thick. On the southern Exmouth Plateau the Barrow-equivalent strata can reach a thickness of up to $2000 \mathrm{~m}$ (although at Site 763 only $414 \mathrm{~m}$ of it was drilled).

The Barrow Group is overlain by the Valanginian to Aptian Muderong Shale. The Muderong Shale can reach a thickness of $300 \mathrm{~m}$ or more in offshore settings. The shale accumulated in a low-energy, offshore marine environment following the
Neocomian transgression. At the Exmouth Plateau sites the Muderong Shale equivalent strata sit unconformably on the Barrow Group sediments (Fig. 4).

The Windalia Radiolarite of late Aptian to earliest Albian age commonly overlies the Muderong Shale. Although the radiolarite is distinctive in outcrop, in the Carnarvon Basin subsurface its presence may be detected only by lowered gamma-ray and sonic well-log values. Its lithology ranges from siltstone to calcilutite (granular calcium carbonate) with a radiolarian content as high as $70 \%$. At the Exmouth Plateau sites the radiolarite cannot be distinguished from the overlying Albian to Turonian Gearle Siltstone (Exon et al., this volume, chapter 12), which consists of a calcareous mudstone with concretions and thin lenses of limestone. Layers of glauconite occur in the upper part. The siltstone accumulated in a low-energy, offshore marine environment with limited terrigenous input.

The Haycock Marl is more calcareous, offshore, equivalent of the Gearle Siltstone in the northern and western Carnarvon Basin. From base to top, it consists of calcilutite, shale, and marl units, of which the middle unit may correspond to a worldwide oceanic anoxic event near the Cenomanian/Turonian boundary, marked by gamma-ray and sonic peaks on well logs throughout the northern Carnarvon Basin (Boyd and Bent, this volume). The upper marl contains foraminifers of Turonian and Coniacian age, deposited in outer shelf to upper slope settings (Exon et al., this volume, chapter 12). At Exmouth Plateau Sites 762 and 763, the Haycock Marl equivalent conformably overlies the Gearle Siltstone equivalent strata (Fig. 4).

The Toolonga Calcilutite rests conformably over the Haycock Marl in most of the Dampier Sub-basin, but elsewhere it is disconformable. It is composed largely of biogenic carbonate with glauconite and pyrite. In well logs it can be identified by lower gamma-ray and sonic values. It is dated as Santonian in the Dampier Sub-Basin and as Santonian to Campanian in the southern Carnarvon Sub-basin (Exon et al., this volume, chapter 12). At Exmouth Plateau sites the Toolonga Calcilutite equivalent conformably overlies the Haycock Marl equivalent strata.

The paleogeographic background of the Exmouth Plateau region has been discussed in a separate introductory chapter (see Exon et al., this volume, chapter 1). Here we will briefly touch on some salient events.

Several episodes of rifting from the Permian to Early Cretaceous along the northeastern region of Gondwana created a new passive margin along northwestern Australia open to the Neo-Tethys to its north. The initial rifting event in the 


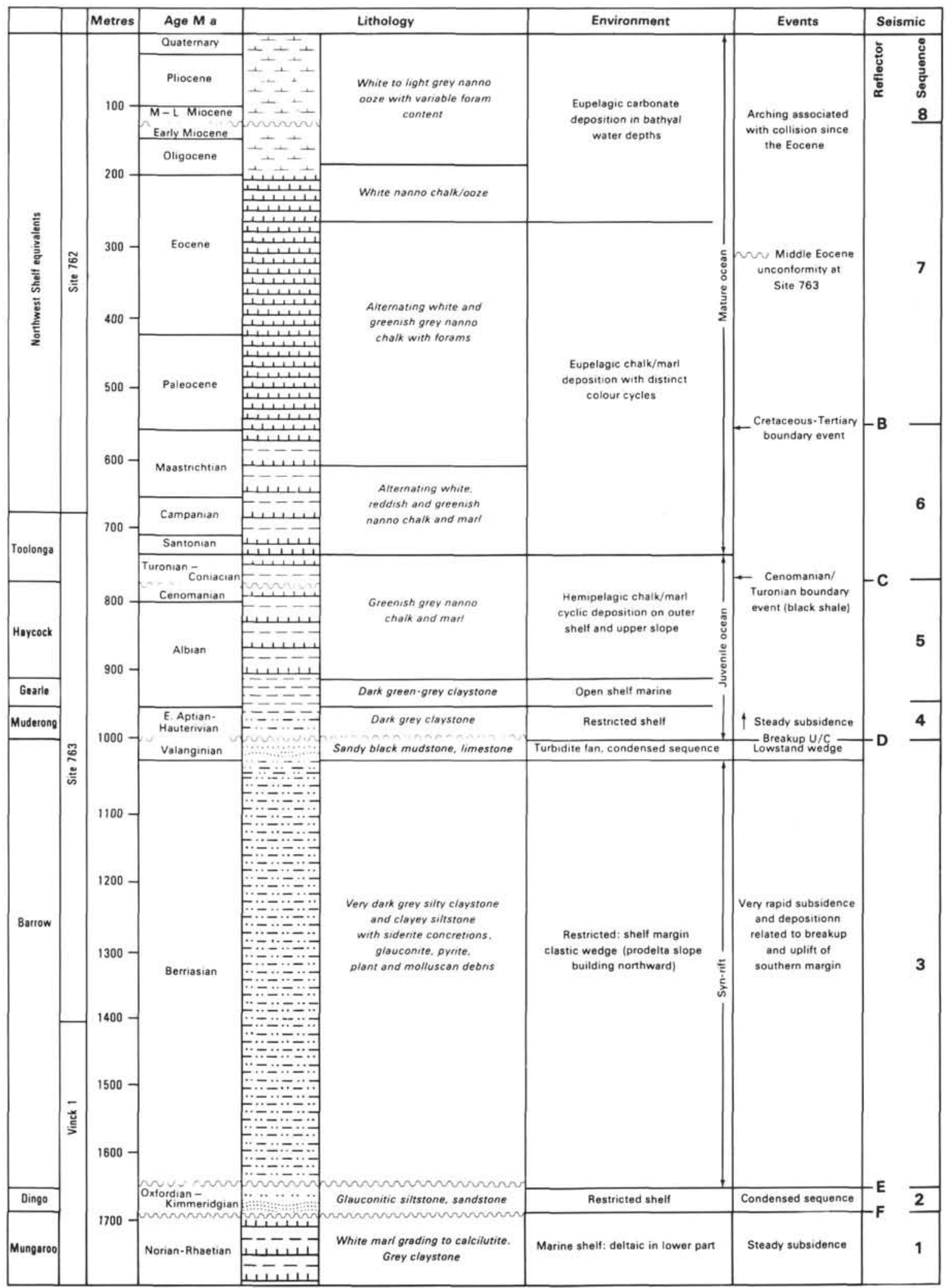

Figure 4. A composite summary of the stratigraphy of the central Exmouth Plateau based on Sites 762 and 763 and commercial well Vinck-1, showing maximum thickness of the Cretaceous and Cenozoic strata drilled (from Exon et al., this volume, chapter 1). 
late Paleozoic (probably Permo-Carboniferous) caused the separation between basement and lower crust underneath northwest Australia and its westward extension to form the Exmouth Plateau (Williamson et al., 1990). Subsidence led to progradation of thick Triassic nonmarine to paralic facies (the Mungaroo Sand/Locker Shale) along the Westralian margin, extending onto the Exmouth Plateau where these facies reach a thickness of up to $3 \mathrm{~km}$. The progradational fluviodeltaic facies was overlain by a thin cover of largely transgressive paralic facies and the deeper water Dingo Claystone equivalents in the Late Triassic and Liassic (Hocking, 1988).

Rifting resumed once again in the Early Jurassic, occurring at different times on different parts of the Exmouth Plateau, and leading to a final phase of breakup in the Neocomian (Audley-Charles, 1988). First to break away was an "Argo Landmass" fragment from the northern margin of the plateau in the Tithonian to Berriasian time (Ludden, Gradstein, et al., 1990). This fragment now may be ensconced in the Asian mainland as Mount Victoria Land of Burma or the Lhasa Block of southern Tibet (von Rad et al., 1989, Görür and Şengör, this volume; see also von Rad et al., this volume). While rifting was proceeding, thick syn-rift sediments accumulated in the grabens of the basins along the northwestern Australian margin. The central Exmouth Plateau, on the other hand, experienced mostly erosion, with only a thin accumulation of marine mud (Barber, 1982). Continued subsidence in the early Neocomian was accompanied by the deposition of marine shales over much of the plateau. The thick clastic wedge of the Barrow Group prograded over the southern and central plateau at this time, sourced from the uplifted hinterland toward the south or the east (see Boyd et al., this volume). An equivalent sediment body along the western edge of the plateau was apparently derived from uplifted TriassicJurassic rift volcanics (Exon and Buffler, this volume).

Breaking away of Greater India and the creation of Cuvier Abyssal Plain to the south and the Gascoyne Abyssal Plain to the southwest took place sometime in the Valanginian to early Hauterivian. This is supported by the presence of anomaly M10 (Hauterivian) as the first recognized magnetic anomaly in these areas (Fullerton et al., 1989), and the early Valanginian to late Berriasian age of the syn-rift sediments overlying the basaltic basement in the Gascoyne Abyssal Plain at Site 766 (Ludden, Gradstein, et al., 1990).

This final fragmentation of the plateau was followed by steady subsidence and the deposition of marine shale (Muderong Shale) until the Aptian (Exon and Wilcox, 1978). A late Aptian hiatus or erosional event was followed by deposition of Albian mudstone and marl (Windalia Radiolarite and Gearle Siltstone equivalent) and the late Albian to Coniacian marl (Haycock Marl). Pelagic carbonate accumulated in the Santonian (Toolonga Calcilutite) and the remainder of the Cretaceous while subsidence continued, followed by the deposition of biogenic oozes in the Cenozoic and deepening of the plateau in the Neogene to its present depth.

\section{DRILLING OBJECTIVES}

The drilling on the northern (Wombat Plateau) and central Exmouth Plateau was designed with multiple objectives in mind. These included:

1. The study of the late-rift and post-breakup sedimentary history and paleoenvironmental evolution of the central Exmouth Plateau.

2. The study of the Cretaceous and Tertiary depositional sequences of the clastic and, later, pelagic depositional environments, of the central Exmouth Plateau. Seismic and welllog data in this region would aid in the sequence-stratigraphic interpretation of siliciclastics-dominated prodelta sediments. This would lead to the testing of both the sequence-stratigraphic depositional models and the new eustatic cycle charts (Haq et al., 1987).

3. The refinement of the Mesozoic magneto- and biochronostratigraphy: Sites 762 and 763 were expected to furnish important new biostratigraphic data for the Cretaceous providing important first-order ties between bio- and magnetochrons.

4. The recovery of complete Cretaceous/Tertiary and Cenomanian/Turonian boundary sections, if possible.

Drilling on the central Exmouth Plateau provided biostratigraphically constrained dating of unconformities, narrowing the age of breakup of the western and southern margins of the plateau. The final breakup of the plateau is now considered to have occurred in the late Valanginian, coinciding with a major unconformity. The unconformity extends from early middle Valanginian to early/middle Hauterivian.

In addition, the recovery of the thick prograding Berriasian/Valanginian sediments of the Barrow Group has been important in gaining an understanding of depositional processes within clastic wedges with large source of terrigenous sediment supply.

Separation of tectonic and eustatic events has helped in deciphering Early Cretaceous sea-level changes on the Exmouth Plateau. Seismic, lithologic, and biofacies data have contributed toward this goal, both on the Exmouth and Wombat plateaus (see von Rad et al., this volume, for a sequence-stratigraphic interpretation of Wombat Plateau sites). Leg 122 wireline-log data were not available for a large part of the relevant section at Sites 762 and 763, but the well logs from nearby commercial wells could be utilized. Several sea-level change events deciphered from sequence-stratigraphic analysis correlate with the global cycle chart (Haq et al., 1987) which will be discussed later.

In the next section we briefly outline the main results of Sites 762 and 763 separately.

\section{RESUME OF DRILLING ON CENTRAL EXMOUTH PLATEAU}

\section{Summary of Results, Site 762}

Site 762 was drilled at $19^{\circ} 53.24^{\prime} \mathrm{S}$ and $112^{\circ} 15.24^{\prime} \mathrm{E}$ in a water depth of $1360 \mathrm{~m}$ (Fig. 1). The site is located on the western part of the central Exmouth Plateau. In this area a thick Triassic paralic section is overlain unconformably by a thin Upper Jurassic marine succession and Lower Cretaceous prodelta sediments, covered by middle Cretaceous to Cenozoic pelagic carbonates.

Site 762 was drilled to a total depth (TD) of $940 \mathrm{~m}$ and recovered a section ranging in age from Berriasian to Quaternary, with an overall recovery rate of $69 \%$. The upper $182 \mathrm{~m}$ of foraminifer-nannofossil and nannofossil oozes of late Oligocene through Quaternary age are underlain by nannofossil chalk of early Paleocene to late Oligocene age with numerous intervals of cyclic color bands. The Cretaceous/Tertiary boundary occurs at $554.3 \mathrm{mbsf}$, within the nannofossil chalk and is marked by a slight color change. The chalky lithofacies continues to 838.5 mbsf, with generally increasing clay content downward, and age ranging from middle Albian to latest Maestrichtian. The Cenomanian chalk contain abundant pressure-solution contacts (stylolites). The Cenomanian/Turonian boundary event is characterized by the presence of organicrich black shale, indicating anoxia. Below 838.5 mbsf a 10 -m-thick unit of black shale of Hauterivian to late Barremian age represents another period of anoxia on the plateau. 
The middle Cretaceous to Paleogene section is essentially complete and in large part well-preserved. The black shale are unconformably underlain by silty claystone and prodelta claystone of the Barrow Group of middle to late Berriasian age. A belemnite-rich horizon below the black shale may reflect the beginning of a major global early Valanginian transgression.

The site yielded an expanded Campanian to Eocene succession with well-preserved calcareous microflora and fauna, suitable for detailed magnetobiostratigraphic and stable-isotopic work. Nannofossils, and to some extent foraminifers, were useful in assigning ages to the pre-Tertiary section. Rich dinoflagellate assemblages were found in the Aptian black shale unit. Palynomorphs were also valuable in assigning the ages of the lower Neocomian Barrow Group sediments.

The hole was logged during three runs to generate seismicstratigraphic, geochemical, and neutron-density logs for detailed correlations and safety considerations regarding the drilling of Site 763. Careful monitoring of hydrocarbon gases revealed relatively high values of methane trapped in Cretaceous and Paleocene chalks between 400 and 850 mbsf, occurring as the dissolved component of pore waters of the sediments. Rock-Eval pyrolysis of the organic matter type revealed it to be of type 3 (woody-coaly, terrestrial). Correlation was possible between the log response, physical properties, and litho- and biostratigraphic data of the site, which compared well with the seismic data from the region and the well-site data from the Eendracht-I well.

\section{Summary of Results, Site 763}

Site 763 is located about $84 \mathrm{~km}$ south of Site 762 on the western part of central Exmouth Plateau at $20^{\circ} 35.19^{\prime} \mathrm{S}$ and $112^{\circ} 12.52^{\prime} \mathrm{E}$ in a water depth of $1367.5 \mathrm{~m}$. Site 762 is located distally and Site 763 more proximally to the terrigenous source of sediments being shed from the southern hinterland during the Jurassic-Early Cretaceous. This is demonstrated by the extensive seismic data in the area that show a thinner Cenozoic but a considerably thicker Cretaceous section at Site 763 than that cored at Site 762 (see Fig. 3).

Site 763 was drilled to a total depth of $1036.6 \mathrm{~m}$ with a relatively high recovery rate of $82 \%$. The cored section ranges from middle Berriasian syn-rift prodelta mudstone to eupelagic Quaternary ooze. The upper $141.7 \mathrm{~m}$ consists of gray to white Quaternary to lower Miocene foraminifer nannofossil ooze unconformably underlain by $105.4 \mathrm{~m}$ of white nannofossil chalk of early Miocene to middle Eocene age. A 30-m.y. hiatus separates the underlying 138.7-m-thick upper Campanian to Turonian greenish, bioturbated chalk with microcycles and Inoceramus fragments. This is underlain by $184.3 \mathrm{~m}$ of upper Cenomanian to middle Aptian greenish-gray, calcareous, zeolitic claystone rich in glauconite, belemnites, and pyrite. A upper Barremian to Aptian black silty claystone underlies this unit. Below the breakup unconformity (prelatest Barremian, post-early Valanginian), $414.1 \mathrm{~m}$ of Barrow Group claystone/siltstone of shelf margin prodelta origin were cored. The upper part consists of $21 \mathrm{~m}$ of glauconite- and belemnite-rich silty claystone to sandy siltstone, dated as Valanginian-late Berriasian in age, underlain by $27.1 \mathrm{~m}$ of sandstone with poor recovery. The lowermost unit down to total depth consists of structureless black to dark gray silty claystone to sandy siltstone with pyrite nodules and siderite concretions. The recovery of the thick Barrow Group sediments was a highlight of this site. These prodelta sediments prograded basinward during the latest rifting stages prior to the late Valanginian onset of seafloor spreading in the adjacent Gascoyne and Cuvier abyssal plains.

\section{DEVELOPMENT OF DEPOSITIONAL SEQUENCES AND EARLY CRETACEOUS EVOLUTION OF EXMOUTH PLATEAU}

The Cretaceous strata on the Exmouth Plateau rest on a condensed sequence of Jurassic shelf sediments (equivalent to Dingo Claystone) or directly on Triassic paralic to fluviodeltaic nonmarine sequences. The thick lowermost Cretaceous (Berriasian) is largely deltaic sediments of the Barrow Group that prograded rapidly northward onto a subsiding basin after the uplift and erosion of the southern hinterland which provided a large load of stream-transported terrigenous clastics. An apparent hiatus from the late Valanginian to Barremian was followed by the deposition of marine mudstone (Muderong Shale equivalent). Another hiatus spanning at least a part of the upper Aptian was succeeded by the accumulation of Albian mudstone and marl (Gearle Siltstone equivalent) and upper Albian to Coniacian marl (Haycock Marl equivalent). Pelagic carbonate sedimentation began in the Santonian (Toolonga Calcilutite equivalent) and continued into the Cenozoic.

We have used a sequence-stratigraphic approach (see Haq, 1991, and references therein for concepts of sequence stratigraphy) to subdivide the Neocomian pre-breakup sediments into genetically related packages (see Fig. 5, back pocket, and Figs. 6-8).

In the distal prodelta setting of the Barrow Group, the depositional sequences typically can be subdivided into lowstand systems tracts (lowstand prograding complexes) and their highstand counterparts, separated by subtle maximum flooding surfaces. In such settings it is particularly useful to use both seismic and litho- and biofacies patterns for sequence-stratigraphic interpretations.

The lowstand systems tract develops following the withdrawal of the sea below the offlap break, which may initially lead to the formation of a lowstand fan complex. The fans are fed by incised canyons that provide point sources for sediments to feed onto the slope or the basin floor. The basin-floor fans are dominated by sand-prone sediments, whereas slope fans may be characterized by complex turbiditic and slump facies (see Haq, 1991, and Vail et al., in press, for details).

The lowstand prograding complex is wedge-shaped and largely composed of shallowing-upward lowstand delta facies that prograde basinward and onlap landward, with a pinchout near the offlap break. In areas of high sediment influx (as on the Barrow Delta) the toes of the prograding lowstand units may interfinger with shingled turbidites that can occur attached to or detached from the clinoforms. Slumps also may characterize the early stages of the lowstand complex when oversteepened slopes of the previous highstand provide high sediment flux. The slumps tend to be more chaotic in the early part of the lowstand complex (Vail et al., in press).

The deposition of the lowstand systems tract concludes at the first major transgression with the change from forestepping, progradational, lowstand facies to backstepping, retrogradational, transgressive facies. The transgressive systems tracts, however, are not expressed fully on the basinward side of the offlap break, as is the case with the Barrow sequences on the central Exmouth Plateau. In this prodelta position, beyond the offlap break, the lowstand systems tract is overlain directly by the distal toes of the clinoforms of the next prograding highstand systems tract, especially when sediment influx rate is high.

The seaward extent of progradation of lowstand and highstand systems tracts will vary with the rate of sediment supply, being extensive during high rates of sediment influx, 
as was the case during the deposition of much of the Barrow Group sediments. During the lowstand, the oversteepened slopes of the previous highstand systems tract become unstable, leading to slumps and contributing to turbidites. Turbiditic and slump features theoretically could develop in both the low- and highstand systems tracts when sediment supply is high. However, on the basinward side of the offlap break, turbiditic and fan complexes can develop in thicker, more localized deposits in the lowstand prograding wedge. Such features are less likely to occur in the distally deposited highstand systems tracts under normal sediment supply situations, since only the distal extension of the highstand clinoforms reaches beyond the offlap break. Instead, these features may occur where highstand facies are thickest (i.e., on the shelf shoreward of the offlap break). However, slumps may drape the slopes beyond the offlap break within both systems tracts, especially in high sediment supply situations.

The central Exmouth Plateau provides an excellent case study of sequences in a prodelta setting with very high terrigenous influx. High sediment accumulation rates, up to 30 $\mathrm{cm} / \mathrm{k} . \mathrm{y}$., occur in the Barrow Group sediments. Elsewhere the sedimentation rates average $2 \mathrm{~cm} / \mathrm{k} . \mathrm{y}$. or less.

On the Exmouth Plateau the overall sea-level change signal within the sediment record is modified due to a tectonic overprint, but the response of the two causal factors can be distinguished.

\section{Sequence-Stratigraphic Analysis of Exmouth Plateau Early Cretaceous}

The sequences of the Berriasian-early Valanginian prodelta section of Site 763 are better developed than those of Site 762. The section is thicker at Site 763 due to its proximal position on the prodelta compared to the distal Site 762. In addition, at Site 763 the seismic-stratigraphic analysis of Boyd et al. (this volume) is of considerable aid in picking the depositional surfaces between systems tracts. These surfaces are relatively difficult to decipher further out in the basin because of the lack of prominent lithologic changes which characterize systems tracts above the offlap break. For these reasons sequence stratigraphy of the thicker and more complete section at Site 763 is discussed before Site 762 .

\section{Site 763}

Both Sites 763 and 762 were located seaward of prograding delta systems during the Early Cretaceous. While Site 763 was only a few tens of kilometers from the offlap break, Site 762 was located in a more distal-basin setting, receiving a considerably lesser load of sediments (Fig. 3) and showing only subtle expressions of change in the depositional patterns associated with different systems tracts.

At Site 763 sequence-stratigraphic analysis (see Fig. 5, back pocket, and Figs. 6 and 8 ) is facilitated by availability of extensive seismic data and useful well logs in the vicinity. For nearly three decades seismic data have been gathered from the Exmouth Plateau to facilitate hydrocarbon exploration in the area. Major seismic surveys and regional syntheses were undertaken by several commercial firms and the Australian Bureau of Mineral Resources and 11 exploratory wells were drilled on the plateau (see Barber, 1988; Williamson and Falvey, 1988; and Exon and Williamson, 1988). Correlation of the Barrow Group sequences with global sea-level cycles also has been attempted by Erskine and Vail (1988) based on seismic data. The most recent of these studies (Boyd et al., this volume) incorporates Leg 122 drilling results.

Boyd et al. (this volume) used a wide range of seismic data to define eight stratigraphic packages (shown in Fig. 2) consisting of three major episodes of clastic deposition blanketed by carbonates. The study provides a regional framework in which a tectono-eustatic model of margin evolution can be evaluated. The study documents an episode of intracratonic sedimentation in the Late Triassic, rifting in the Jurassic, resumed rifting and final breakup in the Late Jurassic and Neocomian, and rift-to-drift transition in the middle Cretaceous, ending in a mature ocean phase enroute to a collisional margin.

Figure 5 (back pocket) shows a seismic section from Boyd et al.'s figure 7 (this volume) and a new line interpretation of depositional features. The lower three seismic-stratigraphic packages are relevant to the discussion of Early Cretaceous sequences, especially package 3 (between reflectors 2 and 3). Hole 763C extended some $85 \mathrm{~m}$ below reflector 34 of package 3 , but did not reach reflector 33 . Figure 5 (back pocket) shows examples of shingled basin-floor turbidites, which occur more commonly within the lowstand prograding complex (LPC) of the lowstand systems tract. In the following discussion we describe the systems tracts and their bounding surfaces, and assign their ages based on the biostratigraphic data (see Figs. $6,7)$. To achieve biostratigraphic consistency for correlations we have related all Barrow Group seismic reflectors to the dinoflagellate zonation of Helby et al. (1987) and Brenner (this volume, chapter 31) tied to the time scale of Haq et al. (1988). Nannofossils provide additional correlations and may occasionally result in marginal age contrast with the dinoflagellate zonation (see Bralower et al., this volume). The resulting biostratigraphic age assignments fit reasonably well with the global cycle chart, and thus, sequence boundaries (SB) and maximum flooding surfaces (MFS) are also designated by absolute ages corresponding to various eustatic events (after Haq et al., 1988).

The lowstand prograding complex is most commonly composed of shallowing-upward parasequences that prograde basinward and onlap landward with a pinchout in the vicinity of the offlap break. On Figure 5 (back pocket) shingled turbidites can be seen interfingering with the toes of the lowstand prograding parasequences. Examples of such shingled turbidites can be seen above seismic reflector 36 (shaded areas). The shingled feature on the offlap break position above reflector 31 , on the other hand, appears to be a slope fan, and those between reflectors 31 and 32 and above reflector 33 are good examples of basin-floor fans. Site 763 is located distal to these examples of turbidites, although all reflectors 34 through 39 were penetrated in Hole 763C (see also Fig. 6).

Figure 6 shows a biostratigraphic, lithologic, tectonic, and sequence-stratigraphic summary of the Lower Cretaceous part of Site 763. The lower Valanginian-Berriasian part of the section (Cores 122-763B-48X to 122-763C-46R) is dated on the basis of palynomorphs (Brenner, this volume, chapter 31 ). The Berriasian can be subdivided into three biozones spanning the middle Berriasian Cassiculosphaeridia delicatus Zone (Cores 122-763C-38R to -46R), middle to late Berriasian Dissimulidinium lobispinosum Zone (Cores 122-763C-21R to $-37 \mathrm{R})$, and late Berriasian Batioladinium reticulatum and Egmontodinium torynum Zones (Cores 122-763B-49X to 122763C-20R). Core 122-763B-48X represents the early Valanginian Systematosphaera areolata Zone (Brenner, this volume, chapter 31). According to Helby et al. (1987) the E. torynum Zone straddles the Berriasian/Valanginian boundary, while the $S$. areolata Zone spans almost the entire early Valanginian. It is probable that at Site 763 a substantial part of Zone $S$. areolata may be missing at the unconformity (Fig. 6).

The post-Valanginian section was dated on the basis of calcareous nannoplankton (Bralower and Siesser, this volume). These data suggest that the breakup unconformity occurred in, or soon after, early Valanginian. This unconfor- 
Site 763

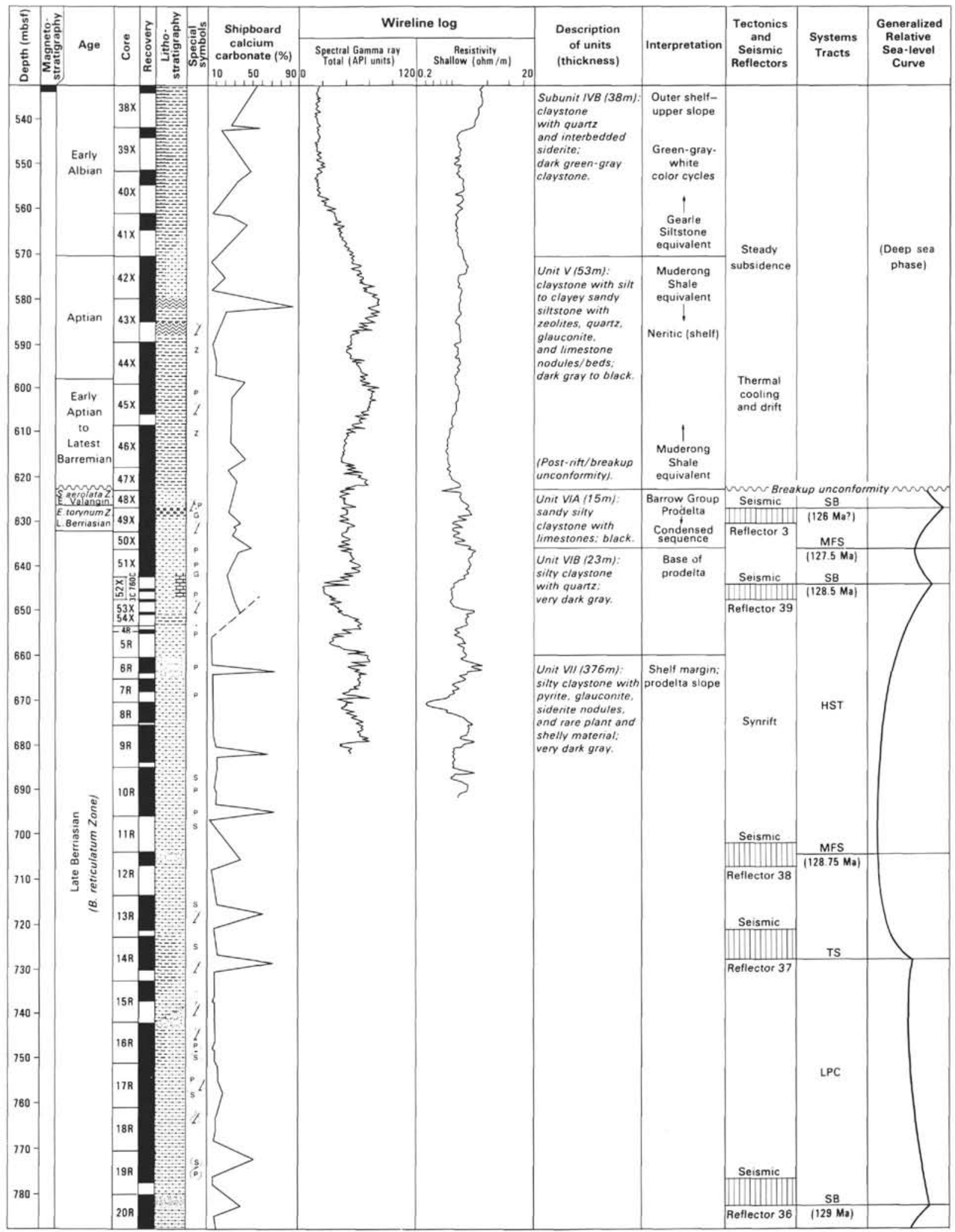

Figure 6. Lithostratigraphy, biostratigraphy, paleoenvironment, tectonic events, depositional systems tracts, and generalized sea-level curve for the Early Cretaceous sequences cored at Site 763. The tectonic column also contains correlations with seismic reflectors identified in Figure 5 (back pocket). For explanation of special symbols column, see legend in the lower righthand corner of figure. 
EVOLUTION OF CENTRAL EXMOUTH PLATEAU

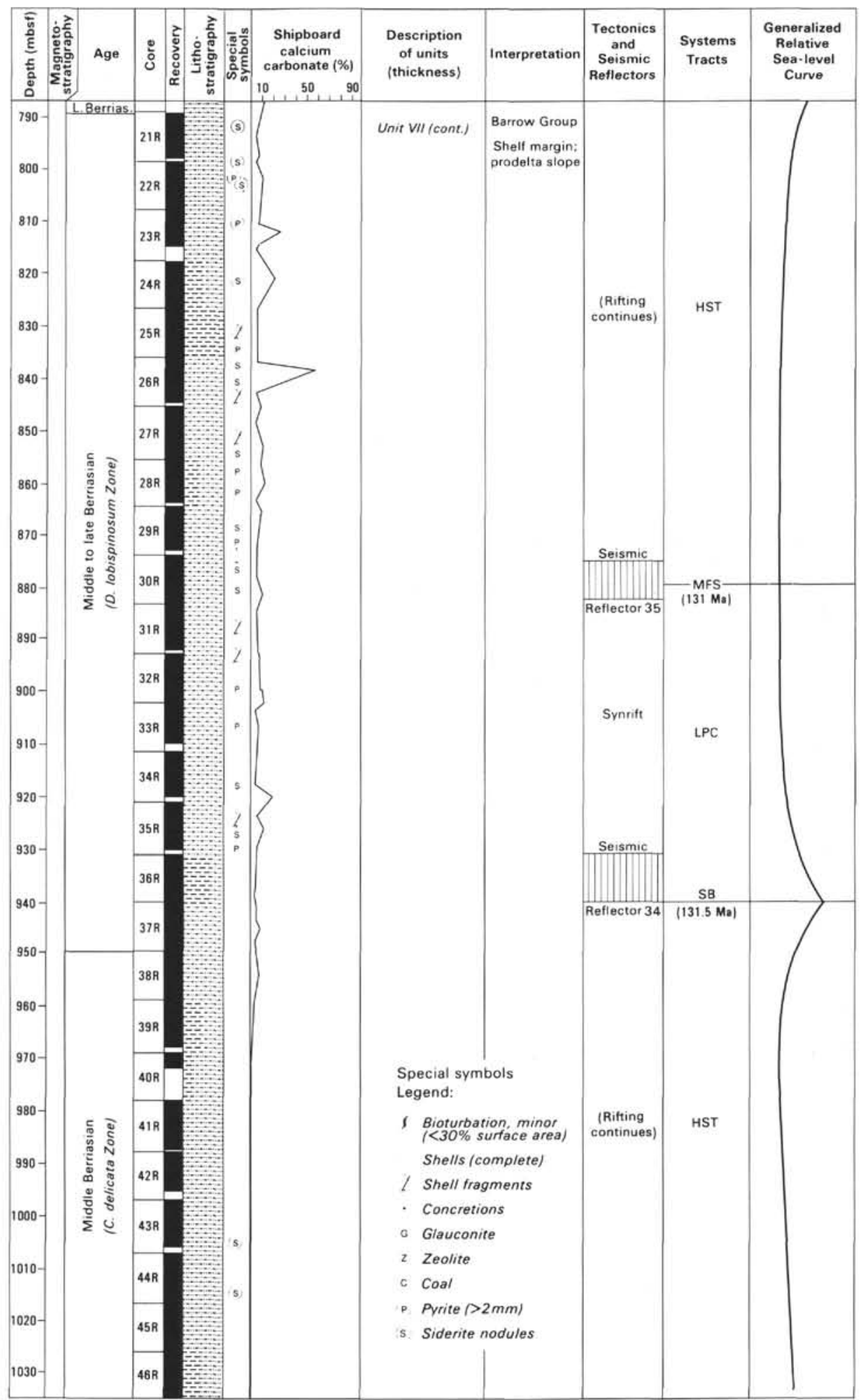

Figure 6 (continued). 
Site 762

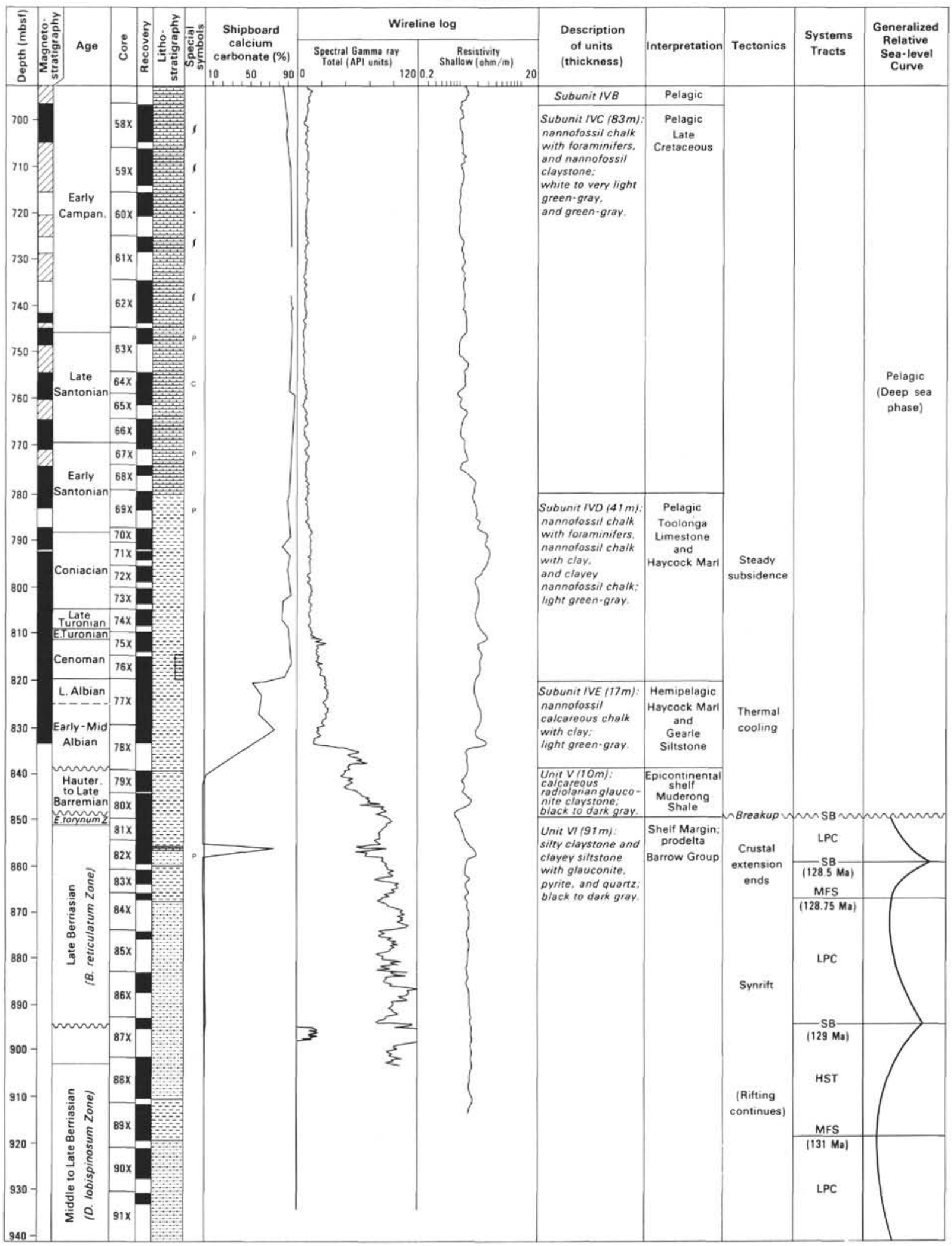

Figure 7. Lithostratigraphy, biostratigraphy, paleoenvironment, tectonic events, depositional systems tracts, and generalized sea-level curve for the Cretaceous sequences cored at Site 762. See Figure 6 for explanation of special symbols column. 


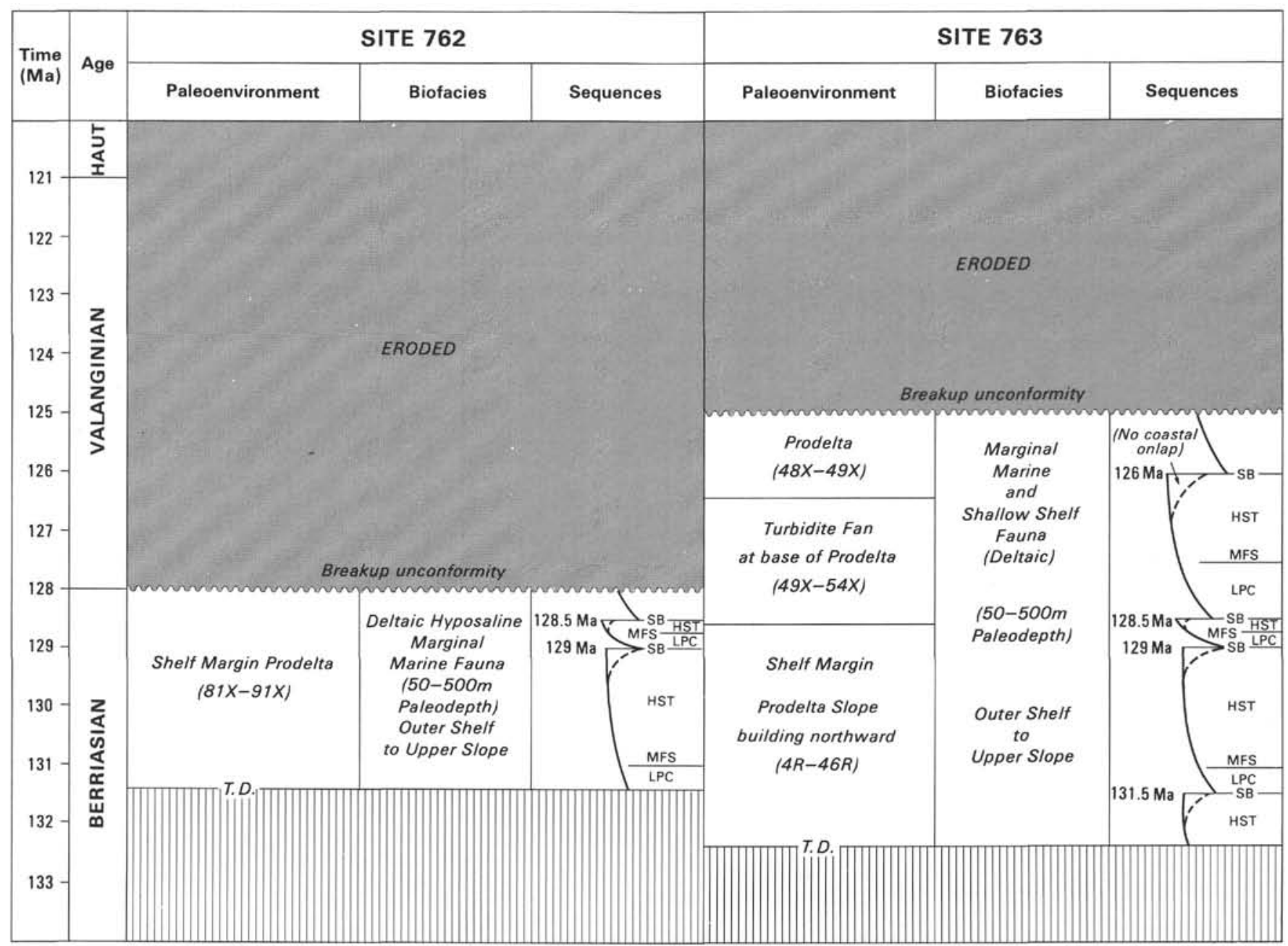

Figure 8. A temporal representation of Neocomian sequences identified in the drilled section of Sites 762 and 763 . The ages in Ma of sequence boundaries (SB) and maximum flooding surfaces (MFS) are from Haq et al. (1988). HST = highstand systems tract; LPC = lowstand prograding complex. The highstand systems tracts of the prodeltaic prograding sequences show marine onlap but no coastal onlap.

mity above the final breakup phase of the plateau was recorded between Cores 122-763B-47X and -48X and is overlain by neritic sediments of latest Barremian to early Aptian age.

Hole $763 \mathrm{C}$ reached its total depth within the highstand systems tract of the underlying sequence, which is overlain by two complete sequences and a condensed sequence near the top, composed largely of prodelta silty claystone with rare coarse-grained sand/silt beds (e.g., those coincident with seismic reflector 36 in Core $122-763 \mathrm{C}-20 \mathrm{R}$, and with reflector 38 in Core $122-763 \mathrm{C}-12 \mathrm{R}$ ). The organic matter within the Barrow-equivalent sediments is of terrestrial higher-plant origin (Rullkötter et al., this volume), and thermally immature (Snowdon and Meyers, this volume).

A sequence boundary is indicated in Core $122-763 \mathrm{C}-36 \mathrm{R}$ (131.5 Ma) coincident with seismic reflector 34 (Fig. 5, back pocket, and Fig. 6). This reflector has clear erosional truncation on seismic lines adjacent to those shown on Figure 5 (back pocket; Boyd et al., this volume). Because of the distal setting, there is only a subtle lithologic change at this boundary, marked by a change in grain size and corresponding subtle trend shifts in density, travel time, and gamma logs in Vinck-I well logs. In such settings beyond the offlap break, there is generally little lithologic change that can be associated with the sequence boundary or maximum flooding surface. A maximum flooding surface (131 Ma) is reached in Core 122-763C-30R, coincident with seismic reflector 35 (see Fig. 6). In the lowstand prograding complex above reflector 34 (Cores $122-763 \mathrm{C}-30 \mathrm{R}$ to $-36 \mathrm{R}$ ) and the highstand systems tract (Cores $122-763 \mathrm{C}-20 \mathrm{R}$ to $-30 \mathrm{R}$ ) lithology changes little, but the depositional environment shallows upward in both systems tracts while the occurrence of pyrite and siderite increases.

A sequence boundary (129 Ma) is indicated in Core 122763C-20R (Fig. 6), marked by a sand-silt bed and coincident with seismic reflector 36 . Shingled turbidites occur in the overlying lowstand prograding complex in the landward direction, showing bidirectional downlap onto this reflector. (The downlap onto reflector 36 is not a downlap of highstand clinoforms whose toes constitute the condensed section. Instead, it is a downlap of individual shingled turbiditic features.)

The sequence boundary is overlain by the distal expression of the lowstand prograding complex seen in Figure 5 (back pocket). Only the distal toes of the prograding lowstand clinoforms extend this far, comprising claystone and silty claystone with pyrite and siderite, suggesting that the complex was deposited in waters shallower than the lowstand prograding complex of the underlying sequence.

A maximum flooding surface $(128.75 \mathrm{Ma})$ is reached in Core $122-763$ C-12R (Fig. 6), marked by seismic reflector 38 . 
Seismic reflector 37, which onlaps shoreward but pinches out basinward (Fig. 5, back pocket), is interpreted to mark a transgressive surface, rather than a maximum flooding surface, where carbonate content also increases upward. Seismic reflector 38 shows downlap of distal toes of the highstand clinoforms onto this surface (cf. the shingled bidirectional downlap onto reflector 36-a sequence boundary-with the downlap on reflector 38-a true downlap or maximum flooding surface). In the later highstand phase the depositional environment progressively shallows upward.

The next higher sequence boundary $(128.5 \mathrm{Ma})$ is encountered within Core 122-763B-52X, above seismic reflector 39 (Fig. 6). Cores 122-763B-52X and -53X and Cores 122$763 \mathrm{C}-4 \mathrm{R}$ and $-5 \mathrm{R}$ are poorly recovered sandstone intervals representing the last coarse-grained clastic influx of the highstand systems tract which is the most likely source of seismic reflector 39 . Overlying this is a maximum flooding surface (127.5 Ma) in the upper part of Core 122-763B-51X, coincident with carbonate and gamma-ray peaks. Above this surface a distal depositional setting starved of clastic sediments is maintained (Cores $122-763 \mathrm{~B}-48 \mathrm{X}$ to $-50 \mathrm{X}$ ). This is evidenced by regionally correlatable limestone intervals in Cores 122 $763 \mathrm{C}-48 \mathrm{X}$ and $-49 \mathrm{X}$. These limestone horizons apparently generate the regional seismic reflector 3 .

A sequence boundary is interpreted at the top of the recrystallized limestone unit within Section 122-763B-48X-3 (Fig. 6). Since this boundary occurs within the $S$. areolata Zone it is tentatively dated as $126 \mathrm{Ma}$, within the middle part of early Valanginian (Haq et al., 1988). Upward, the sequence boundary is closely followed by the breakup unconformity above Core 122-763B-48X, marking a nearly 10-m.y. (late Valanginian to late Barremian) hiatus associated with the final breakup of Exmouth Plateau.

The breakup unconformity is overlain by the latest Barremian to early Aptian claystone (Core 122-763B-42X to -46X; Muderong Shale equivalent), deposited in a neritic shelf environment following a major transgression and accelerated deepening as the rate of basin subsidence increases (Fig. 6).

\section{Site 762}

Only the lower $92 \mathrm{~m}$ section is relevant to the discussion of Neocomian sequence stratigraphy (Figs. 7, 8). This interval (Cores 122-762C-81X to $-91 \mathrm{X}$ ) belongs to the lithologic Unit VI of silty claystone and siltstone deposited in a distal prodelta environment. The depositional surfaces in such distal settings are very subtle and even less conspicuous than proximal areas on the prodelta (cf. with Site 763, Fig. 6). Only the upper two of three sequence boundaries occurring at Site 763 were penetrated at this site (Fig. 7).

The lower part of the unit (Cores 122-762C-87X to $-91 \mathrm{X}$ ) has been assigned to a middle to late Berriasian D. lobispinosum Zone (Brenner, this volume, chapter 31). The overall biofacies suggest a hiatus in Core 122-762C-87X (a latest Berriasian nannofossil zone is missing-Bralower and Siesser, this volume), which marks an unconformity associated with a sequence boundary (129 Ma) within the early part of late Berriasian. The boundary occurs near a peak in the spectral gamma-ray log. The silt-poor claystone in Core $122-762 \mathrm{C}-89 \mathrm{X}$ below the boundary may be a subtle record of a maximum flooding surface $(131 \mathrm{Ma})$ on the very distal prodelta. If this interpretation is correct, then the section below the maximum flooding surface would correspond to a distal expression of the lowstand prograding complex, largely the distal toes of the prograding clinoforms. The unconformity associated with the late Berriasian sequence boundary may have resulted from the erosion of at least part of the section representing late highstand, regressive, upward-shoaling facies (Fig. 7).
The interval above the late Berriasian sequence boundary and below the breakup unconformity (Cores 122-762C-81X to $-87 \mathrm{X}$ ) was assigned to the $B$. reticulatum Zone (Brenner, this volume, chapter 31 ). In addition, glauconitic grains from Core $122-762 \mathrm{C}-81 \mathrm{X}-\mathrm{CC}$ provided a $\mathrm{K} / \mathrm{Ar}$ apparent age of $132 \pm 2$ $\mathrm{Ma}$, corresponding to latest Berriasian on the Haq et al. (1987) time scale (see Odin et al., this volume). A distal expression of the lowstand prograding complex in the lower part of the interval (Cores $122-762 \mathrm{C}-84 \mathrm{X}$ to $-87 \mathrm{X}$ ) has a lithology similar to that in the interval below the unconformity (Fig. 7).

A maximum flooding surface $(128.75 \mathrm{Ma})$ is interpreted in the upper part of Core $122-762 \mathrm{C}-84 \mathrm{X}$, marked by reduced terrigenous input (Fig. 7). This is closely followed by a sequence boundary $(128.5 \mathrm{Ma})$ in Core $122-762 \mathrm{C}-82 \mathrm{X}$. The boundary is placed at the change from late highstand phase siltstone below to a thin calcareous unit above, also marked by a sudden increase in carbonate content and higher gammaray values. The expression of the boundary is quite subtle due to the distal prodelta location of the section.

The breakup unconformity is encountered near the top of Core $122-762 \mathrm{C}-81 \mathrm{X}$ with a hiatus spanning the interval from early Valanginian to at least Hauterivian. The transgressive sediments above the breakup unconformity have been dated as Hauterivian to latest Barremian on the basis of palynomorphs (Brenner, this volume, chapter 31) and as latest Barremian to early Aptian on the basis of nannofossils (Bralower and Siesser, this volume). A hemipelagic to pelagic succession of chalk and ooze were deposited above the Aptian (Fig. 7) when the central Exmouth Plateau area enters a deep-sea "juvenile" ocean phase.

Figure 8 is a temporal representation of the two Berriasian sequences delineated at Site 762 and four Berriasian-Valanginian sequences at Site 763 and their shelf-margin paleoenvironment and biofacies. Because of the distal prodelta setting no coastal onlap is seen on the landward side of the highstand systems tracts. The final breakup event that caused the breakup unconformity cut deeper into the section at Site 762, eroding the section representing the upper (126 Ma) sequence.

\section{MIDDLE CRETACEOUS TO CENOZOIC SEDIMENTATION ON THE EXMOUTH PLATEAU}

Exon et al. (this volume, chapter 12) have discussed the Aptian to Maestrichtian sedimentary patterns on the central Exmouth Plateau in detail.

The transgressive Muderong Shale-equivalent mudstone (Valanginian-Aptian) represents outer-shelf marine facies of the restricted "juvenile" ocean phase. It has high organic carbon and zeolite content, which may be correlative with the worldwide anoxic event. The lower Aptian ("Selli") anoxic event is represented in Cores $122-763 \mathrm{~B}-44 \mathrm{X}$ to $-46 \mathrm{X}(0.5 \%$ $1.8 \%$ total organic carbon, or TOC) and Core $122-762 \mathrm{C}-79 \mathrm{X}$ (up to $0.8 \%$ TOC). The mudstone are overlain by the Gearle Siltstone equivalent strata of the early Albian, with a possible hiatus between the two. The siltstone unit is $38 \mathrm{~m}$ thick at Site 763 , but very thin at Site 762 where it also is marked by an anomaly in resistivity. The biogenic component increases upward at Site 763, indicating deepening and sequestering of terrigenous material. Color cycles are present throughout, recording variations in clay vs. carbonate content, which may be controlled by small-scale climatic periodicities (Exon et al., this volume, chapter 12). The Gearle Siltstone-equivalent sediments are outer shelf mudstone at Site 763 but more chalky at Site 762, and represent a transition from predominantly terrigenous clastic to pelagic carbonate sedimentation and from "juvenile" to "mature" ocean phase.

The Haycock Marl equivalent (middle Albian to Turonian) that overlies the Albian mudstone and chalk consists largely of 
bioturbated nannofossil claystone and chalk and is thicker at Site 763 (Cores 122-763B-21X to -37X), than at Site 762 (Cores 122-762B-73X to -77X). A claystone deposited under anoxic conditions at the Cenomanian/Turonian boundary occurs in Core $122-763 \mathrm{C}-2 \mathrm{R}$. The Cenomanian/Turonian boundary is apparently preserved Site 762 (in Core 122-762B-75X), marked by the presence of a $25-\mathrm{cm}$-thick dark brown shale above the boundary. The black shale in Core 122-763C-2R-1 contains 9\%-15\% TOC (Rullkötter et al., this volume) and records an expanded oxygen-minimum zone impinging on the continental slope (paleodepth of about $500-1000 \mathrm{~m}$ ). Zeolitized radiolarians are common, suggesting upwelling, attributed to the early Turonian eustatic sea-level rise (J. Thurow, pers. comm., 1990). The shale is coincident with a gamma-ray peak in the well logs, indicating organic matter concentration. These shale are correlative with a worldwide oceanic anoxic event at this boundary (Boyd and Bent, this volume).

Much of the Upper Cretaceous on the central Exmouth Plateau is characterized by cyclic variations in the clay vs. carbonate content. Huang et al. (this volume) estimate that these are 21- and 40-k.y. cycles that correlate with the Milankovitch orbital periodicities of precession and obliquity. They ascribe the cyclicity to climatic variations between warm, wet, more erosive periods of runoff and clay influx, and cold, dry, less-erosive periods with reduced clay input into the system and dominant calcareous sedimentation.

The marked decrease in terrigenous influx in the Haycockequivalent strata at Site 763 may represent a lowering of relief of the hinterland. The light/dark cycles in this unit may be correlatable with small-scale (Milankovitch) climatic variations (Exon et al., this volume, chapter 12).

The late Albian-Turonian chalks are overlain by a relatively dense limestone sequence of latest Turonian to earliest Santonian age which is in part equivalent to the Toolonga Calcilutite. At Site 763 this unit is $24.7 \mathrm{~m}$ thick (Cores 122-763B-18X to $-20 \mathrm{X}$ ) but somewhat thinner at Site 762 (19 $\mathrm{m}$; Cores $122-762 \mathrm{~B}-69 \mathrm{X}$ to $-72 \mathrm{X}$ ), consisting mainly of clayey nannofossil chalk, bioturbated in the upper part. Milankovitch-scale cyclicity also is seen in this section, deposited in an outer shelf pelagic environment.

The Toolonga-equivalent sediments are overlain by Upper Cretaceous nannofossil chalks deposited in upper bathyal depths at both sites. At Site 762 this sequence is very thick (325.5 m; Cores $122-762 \mathrm{~B}-43 \mathrm{X}$ to $-68 \mathrm{X}$ ) and represents a nearly complete lower Santonian to Maestrichtian section, followed by lower Paleocene chalk with no visible break at the Cretaceous/Tertiary boundary. However, the $\mathrm{K} / \mathrm{T}$ boundary is apparently not complete (a small gap is evident on the basis of detailed nannofossil biostratigraphic analysis; Bralower and Siesser, this volume). At Site 763 the Upper Cretaceous sequence is compressed ( $99.3 \mathrm{~m}$; Cores $122-763 \mathrm{~B}-8 \mathrm{X}$ to $-17 \mathrm{X}$ ) because the Maestrichtian has been eroded along with the overlying Paleocene-lower Eocene strata. Apparently Site 763 was subject to bottom-water erosion in the later Cretaceous and early Paleogene due to its position in water shallower than that at Site 762. The thick Upper Cretaceous carbonate sequence at Site 763 contains significant amounts of methane-dominated gas in the pore waters (Snowdon and Meyers, this volume). This is dry gas of thermogenic origin that migrated upward from deeper (Triassic) levels through fault planes that act as conduits.

The Cenozoic section at Sites 762 and 763 consists of relatively homogenous nannofossil and foraminiferal chalks and oozes. At Site 762 the Paleogene section is well developed and a nearly complete Paleocene through lower Miocene section may be present. All nannofossil zones from NP1 through NP25 and NN1-NN2 were recorded, although in several intervals the zonal boundaries between two adjacent zones could not be clearly differentiated (Siesser and Bralower, this volume). An almost complete Neogene section (with the exception of Zones NN3 and NN8) also may be present at this site.

At Site 763 the upper Campanian chalk is unconformably overlain by eupelagic nannofossil ooze of middle Eocene age (Siesser and Bralower, this volume). An apparently complete upper Eocene through middle Miocene section is present at this site. Above this section a hiatus spanning approximately $6 \mathrm{~m} . \mathrm{y}$. is followed by a relatively complete upper Miocene to Pleistocene foraminifer-nannofossil ooze sequence.

Braarudosphaera-rich assemblages occur in several levels of lower Oligocene to lower Miocene sections at Sites 762 and 763. Siesser et al. (this volume, chapter 38) ascribe these blooms on the central Exmouth Plateau to mid-ocean upwelling of cool, low-salinity, nutrient-rich waters along a divergent zone, a mechanism similar to that cited to explain Braarudosphaera blooms in other areas of the South Atlantic and Indian oceans. They attribute the absence of such blooms in coeval sediments in the Wombat Plateau sites (Sites 759761,764 ) to a possible latitudinal control, although the latitudinal difference is only a few degrees. It is plausible that the restriction of blooms to the central Exmouth Plateau is related largely to regional nutrient availability rather than purely a latitudinal control. This could have been affected by the favorable bathymetric location of the central Exmouth Plateau for upwelling caused by a western boundary current.

\section{DISCUSSION AND CONCLUSIONS}

The evolution of Exmouth Plateau, from a southern NeoTethyan margin of northeastern Gondwana to fragmented sediment-starved marginal plateau bounded by abyssal plains on three sides spans a history of several rifting and breakup events, superimposed on several episodes of continued subsidence. This evolutionary history is illustrated in Figure 9, based on previous studies as well as those of Legs 122 and 123 in the Exmouth Plateau area. This figure is an attempt to visualize the broad aspects of the history of the plateau as it relates to far-afield plate dynamics as well as regional tectonics. It is a simplified, schematic (non-scalar) representation of tectonics (stretching, rifting, block-faulting, subsidence, and seafloor spreading) that affected the plateau and the deposition of various sedimentary packages on the central Exmouth Plateau. (Various aspects of the evolution of Exmouth Plateau also have been summarized in this volume by Boyd et al.; Exon et al., chapter 1; and von Rad et al.).

The Exmouth Plateau was extensively influenced by tectonics throughout its early history from the Permian through Cretaceous. Its sedimentary patterns are therefore a composite record of tectonics (changes in the rate of subsidence and rift-related uplift pulses), eustatics (sea-level fluctuations), climate, and changes in the rates of sediment supply related back to tectonics and climate. Tectonically, all major events, both within the Carnarvon Basin (of which the Exmouth Plateau is a part) as well as far afield, affected the stratigraphic patterns. Each event caused changes in the rates of subsidence, which in turn influenced changes in relative sea level and depositional sequences on the plateau.

Initial lithospheric stretching and thinning along the northwestern Australian Neo-Tethyan margin occurred near the end of the Paleozoic (possibly in the late Permian), which is a time framework similar to initial crustal extension in the Alpine region. Williamson et al. (1990) envision this initial tectonic phase as having caused the uncoupling of basement and lower crust, extending it westward and thinning the continental crust to form the Exmouth Plateau (see Fig. 2). 


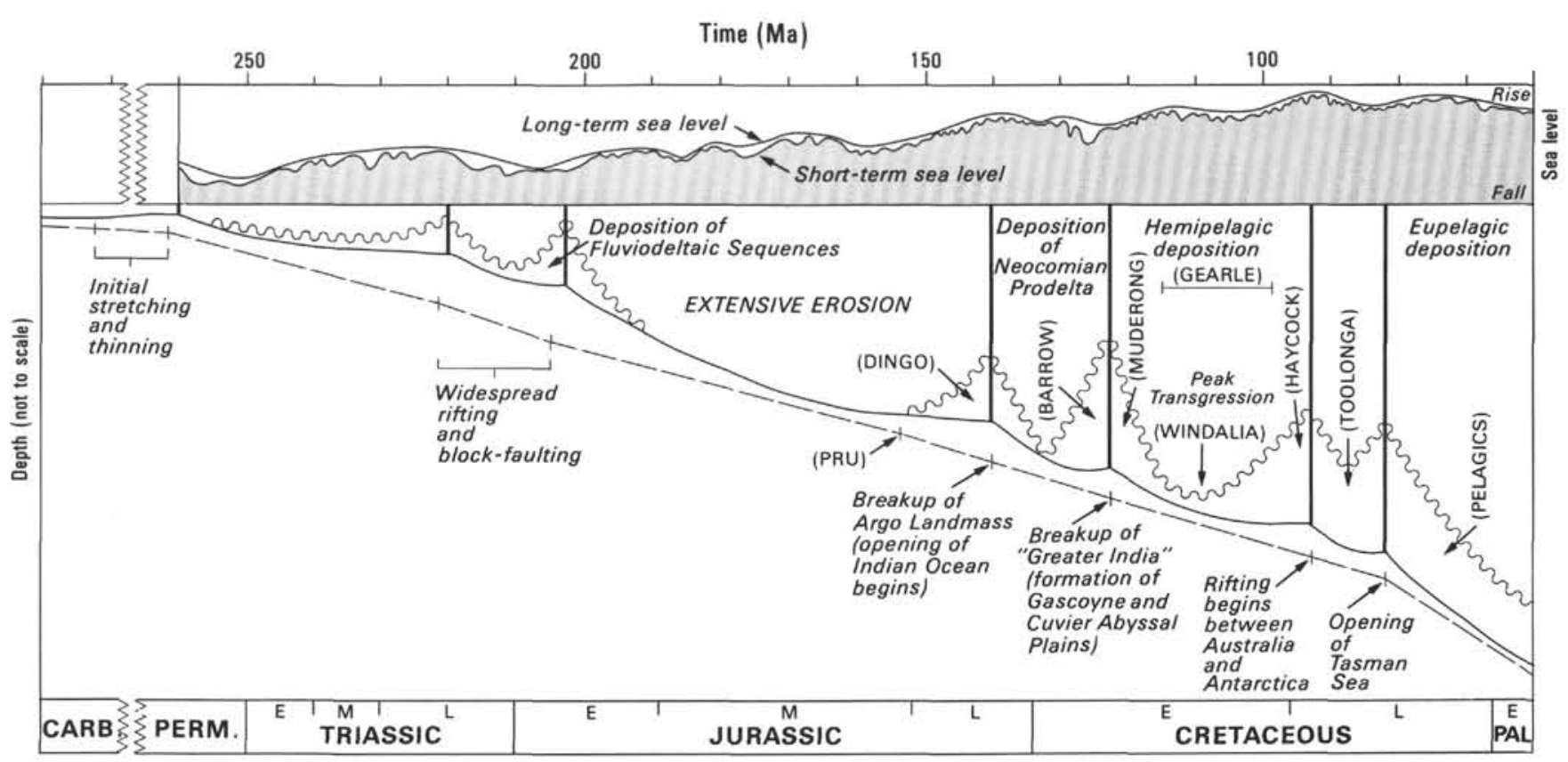

Figure 9. A simplified, schematic (non-scalar) representation of tectonic, depositional, and sea-level history of the Exmouth Plateau. The eustatic curve at the top (after Haq et al., 1987) is given for comparison. Tectonics include both local and far-afield events that may have influenced the evolution of the Exmouth Plateau (see text for further explanation).

Rapid subsidence of the margin created the space necessary for the progradation of thick, largely deltaic sediments in the Triassic. Both subsidence and the rising sea level worked in tandem to deepen the environment of deposition by the Late Triassic. On the Wombat subplateau Late Triassic facies included shallow-water carbonates and shelf-edge reefs (see von Rad et al., this volume).

A major phase of rifting and block-faulting began in the Late Triassic and continued into the Middle Jurassic on the Exmouth Plateau (von Stackelberg et al., 1989; AudleyCharles, 1988), within the same time framework when widespread breakup began over much of Pangaea. These blockfaulting tectonics created a large number of horsts and grabens (see Fig. 2), the latter becoming sites of deposition of thick syn-rift fluviodeltaic sediments in the Barrow/Dampier basins. On the Exmouth Plateau nondeposition and/or subsequent erosion has left only a relatively thin record of Jurassic restricted-marine shelfal sediments (Dingo Claystone) (see Fig. 4).

Breakup between Exmouth Plateau and the "Argo Landmass" occurred in the latest Jurassic (Tithonian) as documented by drilling in the Argo Abyssal Plain (Ludden, Gradstein, et al., 1990). The breakup was preceded by widespread uplift and erosion during the Late Jurassic on the Exmouth Plateau and elsewhere in the Carnarvon Basin, marked by a major unconformity. The thick Barrow Group prodelta sediments began to be deposited in the earliest Cretaceous (Berriasian) in response to both rapid subsidence on the central Exmouth Plateau and uplift at the future Cape Range Fracture Zone, shedding large amounts of clastics from a southern and/or eastern source. Exon et al. (this volume, chapter 1) discuss evidence for the formation of a major ridge (up to $2 \mathrm{~km}$ high) at the location of the Cape Range Fracture Zone in response to thermal doming prior to breakup. Such a feature would certainly have been capable of supplying the clastics needed for the extensive progradation of Barrow Group sediments. The ridge is thought to have collapsed in the Valanginian at the time of final fragmentation of the plateau.
The final episode of breakup of the Exmouth Plateau occurred in the late Valanginian when Greater India broke away from the southwestern margin of the plateau, creating the Gascoyne Abyssal Plain to the west and Cuvier Abyssal Plain to the south. The Carnarvon Basin continued to subside in response to crustal entropy in the Neocomian and later. The deepening of the basin from Neocomian to Aptian is first evidenced in the transgression by Hauterivian-Aptian $\mathrm{Mu}$ derong Shale over Barrow Group sediments, and by increasingly hemipelagic sedimentation thereafter. The clastic influx decreased upward as facies changed from Muderong Shale sequences to the increasingly more pelagic Gearle Siltstone and Haycock Marl equivalents. (Elsewhere, the Windalia Radiolarite represents a period of maximum transgression; see Fig. 9).

Other tectonic events that influenced the sedimentary patterns on the Exmouth Plateau were relatively distant. The timing of the beginning of rifting between Australia and Antarctica in the Turonian and the opening of the Tasman Sea in the Santonian are both marked by unconformities on the Exmouth Plateau (see Fig. 9).

Continued deepening and further sea-level rise in the Late Cretaceous changed the largely hemipelagic deposition of the middle Cretaceous to eupelagic chalk and marl of the Turonian through early Tertiary. The Toolonga Calcilutite represents a transition between these two phases. The plateau had essentially reached bathyal depths by Cenomanian-Turonian time.

Figure 10 shows the estimated subsidence at Site 762 on the Exmouth Plateau from the Early Cretaceous through Holocene. Benthic foraminiferal biofacies tied to the estimates of depths of offlap break and downlap surfaces on seismic profiles provided the first-order bathymetric estimates for calculating subsidence rates (Erskine and Vail, 1989). The input parameters included sediment thicknesses of biostratigraphically dated horizons, biostratigraphic age for each stratigraphic increment in million of years (on the time scale of Haq et al. 1987), measured porosities as a function of lithology 


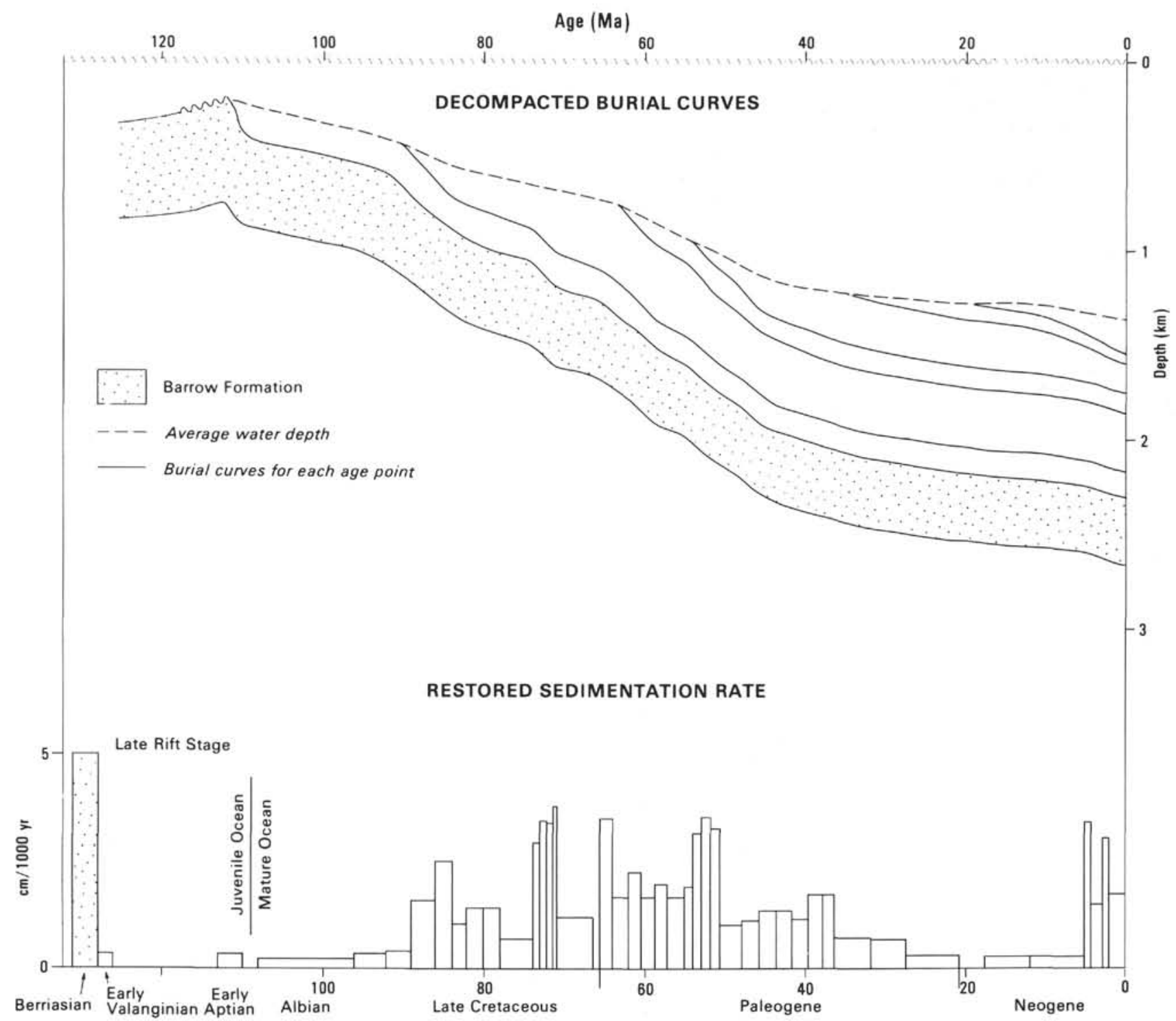

Figure 10. Subsidence (decompacted burial curves, upper) and restored sedimentation rates (lower) at Site 762 on the central Exmouth Plateau (see Gradstein et al., 1989, for decompaction and restoration programs).

and depth (O'Brien et al., this volume), paleo-water depth estimates based on benthic foraminifers (Jones and Wonders, this volume), and eustatic sea-level heights. The resulting figure shows both the decompacted burial curves and restored sedimentation rates.

The Berriasian Barrow Group sediments show high sedimentation rates (average $5 \mathrm{~cm} / \mathrm{k} . \mathrm{y}$.), whose deposition is followed by relative shallowing of the basin (loss of accommodation space after the major depositional episodes) and the final rift stage (breakup of Gascoyne and Cuvier abyssal plains) of the late Valanginian. Increased subsidence in the early Aptian led to deposition of transgressive organic-rich claystone in a deeper shelfal setting. Subsidence rates slowed somewhat in the Albian as the mature ocean phase began and the deposition became increasingly more pelagic. Subsidence rates increased once again in the Turonian, apparently coincident with the timing of the beginning of rifting between Australia and Antarctica. Thereafter, the plateau deepened nearly uniformly until the middle Eocene when the subsidence rates slowed again; there may have been a slight uplift at Site
763 (documented by sediment reworking), apparently in response to the initial collision of India with the Asian mainland, which reduced seafloor spreading rates throughout the eastern Indian Ocean (Haq, 1989). Sediment accumulation rates increased during the latest Cretaceous and remained high through much of the early Paleogene, tapering off in the Oligocene and Miocene.

Drilling on the Exmouth Plateau achieved most of the objectives set out for the leg. The dating of unconformities associated with tectonic events helped to narrow the range of ages of rifting and seafloor spreading events on and around the plateau. Here the evolution of a largely sediment-starved passive margin can be clearly followed from the first stretching and thinning to the late phase of steady subsidence and pelagic sedimentation.

The Neocomian Barrow Group sedimentation on the central Exmouth Plateau provides an valuable example of an ancient prodelta environment, where sediment supply is the overriding variable (see Fig. 8). The lessons learned here add an important case study to the understanding of sequence- 
stratigraphic concepts and sequence geometries in an area of high clastic influx.

Refined Mesozoic and Cenozoic multifossil biostratigraphy has been worked up on the basis of cores from Leg 122 . Magnetostratigraphic results, although less extensive than had been hoped for, provide a detailed magnetochronology for some parts of the section [Hole $762 \mathrm{C}$, early Campanian to middle Eocene (Galbrun, this volume, chapter 42); and Neogene of Site 762B (Siesser et al., this volume, chapter 40)].

Finally, given the biostratigraphic resolution available from the sections recovered during Leg 122, the sea level-change events on the central Exmouth and Wombat plateaus that could be distinguished from tectonic anomalies, show apparent good correlations with the eustatic curves (Haq et al., 1987). Considering the general lack of major glaciations throughout the Mesozoic, these correlations reinforce the suggestion that a nonglacial mechanism of global proportions was operative in the Mesozoic which caused global sea-level fluctuations (see Haq, 1991, for further discussion). Deciphering the nature of this mechanism remains a major challenge in Earth history.

\section{ACKNOWLEDGMENTS}

This paper was reviewed by John Milliman, Suzanne O'Connell, Pat Quilty, and Peter Vail. Their input is gratefully acknowledged. The figures in this paper were drafted at Bureau of Mineral Resources, Canberra, by Rex Bates and Mirra Huber.

\section{REFERENCES}

Audley-Charles, M. G., 1988. Evolution of southern margin of Tethys (North Australian region) from early Permian to late Cretaceous. In Audley-Charles, M. G., and Hallam, A. (Eds.), Tethys and Gondwana. Geol. Soc. Spec. Publ. London, 37:79-100.

Barber, P. M., 1982. Paleotectonic evolution and hydrocarbon genesis of the central Exmouth Plateau. APEA J., 22:131-144.

1988. The Exmouth Plateau deep water frontier: a case history. In Purcell, P. G., and Purcell, R. R. (Eds.), The North West Shelf, Australia: Proc. Pet. Expl. Soc. Aust. Symp., 173187.

Boote, D.R.D., and Kirk, R. B., 1989. Depositional wedge cycles on an evolving plate margin, western and northwestern Australia. AAPG Bull., 73:216-243.

Bradshaw, M. T., Yeates, A. N., Beynon, R. M., Brakel, A. T., Langford, R. P., Totterdell, J. M., and Yeung, M., 1988. Paleogeographic evolution of the North West Region. In Purcell, P. G., and Purcell, R. R. (Eds.) The North West Shelf, Australia: Proc. Pet. Expl. Soc. Aust. Symp., 29-54.

Erskine, R., and Vail, P. R., 1988. Seismic stratigraphy of the Exmouth Plateau. In Bally, A. W. (Ed.), Atlas of Seismic Stratigraphy (Vol. 2). AAPG Stud. in Geol., 27:163-173.

Exon, N. F., von Rad, U., and von Stackelberg, U., 1982. The geological development of the passive margins of the Exmouth Plateau off northwest Australia. Mar. Geol., 47:131-152.

Exon, N. F., and Willcox, J. B., 1978. Geology and petroleum potential of the Exmouth Plateau area off Western Australia. AAPG Bull., 62:40-72.

Exon, N. F., and Williamson, P. E., 1988. Preliminary post-cruise report, Rig Seismic research cruises 7 and 8: sedimentary basin framework of the northern and western Exmouth Plateau. Bur. Min. Resour. Aust. Rec., 1988/30.

Falvey, D. A., 1974. The development of continental margins in plate tectonic theory. APEA J., 14:95-106.

Fullerton, L. G., Sager, W. L., and Handschumacher, D. W., 1989. Late Jurassic-Early Cretaceous evolution of the eastern Indian Ocean adjacent to Northwest Australia. J. Geophys. Res., 94:2937-2953.
Gradstein, F. M., Fearon, J. M., and Huang, Z., 1989. BURSUB and DEPOR version 3.50 -two FORTRAN 77 programs for porosity and subsidence analysis. Open-File Rep.-Geol. Surv. Can., 1283:1-10.

Haq, B. U., 1989. Geological evolution of the Indian Ocean with special reference to the Arabian Sea. In Thompson, M. F. (Ed.), Marine Science of the Arabia Sea. Am. Inst. Biol. Sci., 9-35. 1991. Sequence stratigraphy, sea-level change, and significance for the deep sea. Spec. Publ. Int. Assoc. Sedimentol., 12:1-36.

Haq, B. U., Hardenbol, J., and Vail, P. R., 1987. Chronology of fluctuating sea levels since the Triassic. Science, 235:1156-1166. P. R., 1988. Mesozoic and Cenozoic chronostratigraphy and eustatic cycles. In Wilgus, C., et al. (Eds.), Sea-Level Change-An Integrated Approach. Soc. Econ. Paleontol. Mineral. Spec. Publ., 42:71-108.

Haq, B. U., von Rad, U., O'Connell, S., et al., 1990. Proc. ODP, Init. Repts., 122: College Station, TX (Ocean Drilling Program).

Helby, R., Morgan, R., and Partridge, A. D., 1987. A palynological zonation of the Australian Mesozoic. In Jell, P. A. (Ed.), Studies in Australian Mesozoic Palynology. Mem. Assoc. Australas. Palaeontol., 4:1-94.

Hocking, R. M., 1988. Regional geology of the northern Carnarvon Basin. In Purcell, P. G., and Purcell, R. R. (Eds.), The North West Shelf, Australia: Proc. Pet. Expl. Soc. Aust. Symp., 97-114.

Hocking, R. M., Moors, M. T., and van der Graaff, W.J.E., 1987. The geology of the Carnarvon Basin, Western Australia. Bull.-Geol. Surv. West. Aust., No. 133.

Lemoine, M., and Trümpy, R., 1987. Pre-oceanic rifting in the Alps. Tectonophysics, 133:305-320.

Ludden, J. N., Gradstein, F. M., et al., 1990. Proc. ODP, Init. Repts., 123: College Station, TX (Ocean Drilling Program).

Mauffret, A., and Montadert, L., 1987. Rift tectonics on the passive continental margin of Galicia (Spain). Mar. Pet. Geol., 4:49-70.

Mutter, J. C., Larson, R. L., and Northwest Australia Study Group, 1989. Extension of the Exmouth Plateau, offshore northwestern Australia: deep seismic reflection/refraction evidence for simple and pure shear mechanisms. Geology, 17:15-18.

Vail, P. R., Audemard, F., Bowman, S. A., Eisner, P. N., and Perez-Cruz, G., in press. The stratigraphic signatures of tectonics, eustasy, and sedimentation. In Seilacher, D., and Eisner, G. (Eds.), Cycles and Events in Stratigraphy: Amsterdam (Elsevier).

Veevers, J. J., and Powell, C. McA., 1979. Sedimentary wedge progradation from transform-faulted continental rim: southern Exmouth Plateau, western Australia. AAPG Bull., 63:2088-2096.

von Rad, U., Thurow, J., Haq, B. U., Gradstein, F., Ludden, J., and ODP Leg 122/123 Shipboard Scientific Parties, 1989. Triassic to Cenozoic evolution of the NW Australian continental margin and the birth of the Indian Ocean (preliminary results of ODP Legs 122 and 123). Geol. Rundsch., 78:1189-1210.

von Stackelberg, U., Exon, N. F., von Rad, U., Quilty, P., Shafik, S., Beiersdorf, H., Seibertz, E., and Veevers, J. J., 1980. Geology of the Exmouth and Wallaby Plateaus off northwest Australia: sampling of seismic sequences. BMR J. Aust. Geol. Geophys., 5:113140 .

Williamson, P. E., and Falvey, D. A., 1988. Preliminary post-cruise report, Rig Seismic research cruises 7 and 8: deep seismic structure of the Exmouth Plateau. BMR Geol. Geophys. Rec., 1988/31.

Williamson, P. E., Swift, M. G., Kravis, S. P., Falvey, D. A., and Brassil, F., 1990. Permo-carboniferous rifting of the Exmouth Plateau region, Australia: an intermediate plate model. In Pinet, B., and Bois, C. (Eds.), The Potential of Deep Seismic Profiling for Hydrocarbon Exploration: Paris (Editions Technip), 235-248.

Date of initial receipt: 12 October 1990

Date of acceptance: 20 March 1991

Ms 122B-182 